\title{
USING THE LEARNING OF RECIPROCAL TEACHING BASED ON OPEN ENDED TO IMPROVE MATHEMATICAL CRITICAL THINKING ABILITY
}

\author{
Widodo Winarso ${ }^{a x}$, Putri Hardyanti ${ }^{b}$ \\ a, b Tadris Matematika IAIN Syekh Nurjati Cirebon, Jawa barat, 45132, Indonesia \\ ${ }^{\mathrm{x} C}$ Corresponding author: widodoiain@gmail.com
}

\begin{abstract}
This study aims to determine the application of reciprocal teaching approach assisted by open-ended problem questions which have implications in improving the mathematical critical thinking skills of students in class VII of SMPN 1 Weru Cirebon. This type of research is true experimental research in a randomized pretest-posttest control group design. The instruments used in this study were questionnaires and tests of students' mathematical critical thinking skills. The data analysis technique used is descriptive statistics and inferential statistical analysis with the F test (One Way ANOVA). Based on the results of the descriptive analysis, the responses of the experimental class 1 students > the response of the experimental class 2 students (76.94> 73.42), the results of the improvement in students' critical thinking skills obtained by the experimental class Gain value 1> experiment $2>$ control $(0.65>0,56>0.48)$. Based on the inferential analysis, obtained $F_{\text {count }}>F_{\text {table }}(25,213>$ $5,34)$ and Sig value $<0,05$, then $\mathrm{HO}$ is rejected, meaning there are significant differences between the three classes. Furthermore, the Tukey's HSD test was obtained that the mean difference value of the experimental class $1>$ experiment $2>$ control. Then it can be concluded that the application of the reciprocal teaching model assisted with the open-ended problem has implications in improving the mathematical critical thinking skills of the students.
\end{abstract}

Keywords: Reciprocal teaching approach, Open-ended problem, Critical thinking, Mathematics

\section{INTRODUCTION}

Education is an important role in the quality of human life. In the 21st century competition is getting tougher so that educational activities cannot be ignored (Palmer, 2002). Law No. 20 of 2003 concerning the National Education System, serves to develop capabilities and shape dignified national character and civilization in order to educate the nation's life, aiming at the development of students' potential to become human beings who believe and fear the Almighty, noble, healthy, knowledgeable , capable, creative, independent, and a democratic and responsible citizen. The purpose of education is as a direction for students to grow up according to their true potential and self-concept, and to be able to compete and maintain their lives in the future that is full of changes and challenges. Therefore, teachers as educators must have an awareness of improving the quality of students optimally in order to create quality education (Biggs, 2001). The quality of education can be increased can start from the learning process (Winarso, 2015). Effective learning can help students to improve their abilities according to basic competencies that must be achieved. This will happen if the teacher can design a learning process that is able to bind students to be active in learning, make learning more relevant, fun, and present learning experiences that evoke thinking skills (Vickers, 1990).

Based on observations in class VII of SMP Negeri 1 Weru on April 3, 2018 shows that the low response of students in mathematics learning activities, it can be seen that most students think that mathematics is a difficult lesson so that it is lazy to take mathematics lessons, as well as active students in when conducting discussions it is still low, that is, lack of enthusiasm during the discussion. And through interviews with mathematics teachers at 1 Weru Junior High School in Cirebon Regency, students' critical thinking skills in mathematics learning were still 
low, because it was seen from most students when given a description of questions, not a few students found it difficult to do it, in this case, students were still lacking use his thinking skills more deeply. Therefore, students' critical thinking skills need to be improved.

Mathematics learning generally teachers use learning models with lecture methods and are teacher-centered. So that students are only passive subjects who receive more information from teachers and fewer opportunities are given to students to develop their thinking skills. The learning process that tends to be teacher-centered causes students not to develop their own abilities (Dowaliby \& Schumer, 1973; Granger, et al., 2012). In general, learning is only emphasized in memorizing formulas rather than understanding concepts and getting used to open problems. Where the procedures for resolving these closed mathematical problems are almost standard or standard. Meanwhile, openended problems are almost untouched, teachers have hardly ever been presented in the process of learning mathematics (Boaler, 1998; Oreck, 2004). As a result, it does not rule out the possibility that it will gradually reduce the students' lack of critical thinking skills if they are only given questions that are only fixed on one answer or only with a single solution.

The learning model can be used as a pattern of choice, meaning that the teacher may choose a suitable learning model according to the needs so that the learning objectives can be achieved. One of the learning models applied in mathematics learning is the reciprocal teaching model assisted by open-ended problem questions from the many learning approaches (Oczkus, 2018; Baker, 2017).

Reciprocal teaching is a teaching procedure developed by Brown and Palinscar in the results of his research namely "Reciprocal teaching of comprehension-fostering and comprehension-monitoring activities" (Palinscar \& Brown, 1984). Whereas according to Trianto (2007) inverse teaching (reciprocal teaching) is a constructivist approach based on the principles of making/submitting questions. Reverse teaching is mainly developed to help teachers use collaborative learning dialogues to teach reading comprehension independently in class. Through reciprocal teaching students are taught four strategies for understanding specific selfregulation, including summarizing, making questions, clarifying/re-explaining, and predicting (Brown \& Palincsar, 1984).

Research conducted by Hastanti (2009) concluded that students 'critical thinking skills subject to reciprocal teachinglearning models were better than students' critical thinking abilities subjected to conventional learning. It turns out that mathematics learning by applying the reciprocal teaching model can improve students' thinking skills. This is in line with Sawada in Wijaya (2011) who mentions one of the advantages possessed by the open-ended problem, namely the use of open-ended questions giving experience to reasoning to students. By providing different solutions, students need to provide reasons related to the solutions and strategies they have. This provides an opportunity for students to think and argue mathematically.

Critical thinking according to Kusmanto (2014) can be interpreted as a process of using active and rational thinking skills with full awareness and consideration and evaluation of information. While the purpose is to make decisions (Jacob, \& Sam, 2008). According to Ennis in Husnidar, Ikhsan, \& Rizal (2014) critical thinking is a thought with the aim of making reasonable decisions about what is believed or what will be done. This means that thinking skills using logic. Logic is a way of thinking to get knowledge accompanied by truth assessment based on certain reasoning patterns (Lakatos, 2015). Likewise with Scriven's argument in (Fisher, 2009) reveals that critical thinking is a skilled and active interpretation and evaluation of observation and communication, information, and argumentation. When associated with mathematics learning, students' critical thinking skills are the ability to think in solving mathematical problems that involve reasoning, verification, and mathematical knowledge. Based on these descriptions, the critical thinking referred to in this study is thinking activities to obtain knowledge and understanding and the ability to be able to use mathematical 
concepts and basic principles in making indepth decisions that can be accounted for.

Based on this conception, the purpose of this study is to determine students 'responses to the implementation of reciprocal teaching models assisted by open-ended problem in mathematics learning, knowing how much improvement in students' critical thinking skills through the application of reciprocal teaching models assisted with open-ended problem, as well as the application of the reciprocal teaching model assisted by open-ended questions is a problem with students' mathematical critical thinking abilities.

\section{LITERATURE REVIEW}

\section{Critical thinking in mathematics learning}

Efforts to develop the critical thinking skills of mathematics have become the main agenda in the curriculum of mathematics education worldwide (NCTM, 2000; Mason, Burton and Stacey, 2010; Innabi and Sheikh, 2006). Many researchers have shown that the development of critical thinking skills can improve mathematics achievement (NCTM, 2000; Silver \& Kenney, 1995; Semerci, 2005; Jacob, 2012; Chukwuyenum, 2013). Similarly, critical thinking skills will encourage students to think independently and solve problems in school or in the context of everyday life (NCTM, 2000; Jacob, 2012). The education system in Indonesia is still focused on the exam. Therefore the practice of teaching focuses on subject content and ignore the development of students' thinking skills (Soedjadi, 2000; Rohaeti, 2010). Most of the teaching and learning process that takes place in school is the lecture method, which is based on memorization of facts that leads students to think less critical (Cobb et al., 1992; Duplass \& Ziedler, 2002). Thus, negligence of the importance of thinking skills in teaching and learning affects students' ability to think (Henningsen \& Stein, 1997; Zohar \& Dori, 2003). This leads to students' thinking ability in Indonesia is at a low level. Low ability among Indonesian students is shown by the study TIMSS 2011 and PISA 2012. Study Trends in Mathematics and Science Study (TIMSS, 2011) to form two secondary school students showed that students of Indonesia ranked 38th in mathematics from 42 countries (Mullis et al., 2012). While the results of PISA 2012 survey found Indonesian students at position 64 of the 65 countries in mathematical literacy skills (OECD, 2014). The study revealed that Indonesian students' answer efficiently in the arithmetic problem but weak in nonroutine problem solving involving revelations, give opinions and make reasoning. This finding has prompted the Ministry of Education of the Republic of Indonesia to strengthen efforts to improve the quality of mathematics learning in school.

According to Facione (2011), the most basic concept of critical thinking is the ability of interpretation, analysis, evaluation, inference, explanation, and self-regulation. While critical thinking skills by Onosko and Newmann (1994) may challenge the students to interpret, analyze or manipulate information. Therefore, the critical thinking skills needed when we try to understand something of information that will be used for the triggering of ideas (Ennis, 1996). Similarly, critical thinking requires a student to use new information or manipulate existing knowledge and information so as to obtain reasonable responses to new situations (Lewis \& Smith, 1993; Perkins \& Murphy, 2006). Ennis (1996) opined that critical thinking is reflective thinking that focused on patterns of decision making about what must be believed and what must be done. In the context of mathematical problem solving, Krulik and Rudnick (1995) stated that critical thinking is analytical thinking and reflection that involving testing activities, questioning, connecting and evaluating all aspects of a situation or problem. Critical thinking skills are very important in mathematics learning because these skills can improve the quality of mathematics learning in better and meaningful, so, therefore, should be a systematic way to develop such skills through mathematics learning in school (Cobb et al., 1992).

Mathematics is one of the subjects that can develop critical thinking skills is (Rajendran, 2010; Aizikovitsh \& Amit, 2010). Critical thinking skills in 
mathematics is the process of critical thinking with related to knowledge of mathematics, mathematical reasoning and mathematical proofs in mathematical problem solving (Krulik and Rudnick, 1995). In this study, the evaluation of critical thinking skills in mathematics using three components, namely (1) identification and interpretation of information, (2) information analysis, and (3) evaluation of evidence and argument (Krulik and Rudnick, 1995; Glazer, 2001; Ennis, 1996; Facione, 2011).

\section{Reciprocal teaching approach}

According to Rosenshine \& Meister (1994), Reciprocal Teaching is a learning approach that applies four independent understanding strategies, namely concluding teaching materials, compiling questions and completing them, explaining the knowledge that has been obtained, then predicting the next question from the problem presented to students. The benefit is that it can increase students' enthusiasm in learning because students are required to actively discuss and explain the results of their work properly so that mastery of concepts in a subject of mathematics can be achieved (Baker, Gersten \& Lee, 2002). It is expected that with this approach students will not only memorize a number of formulas on the subject matter of the circle, but also understand the concepts of the formula as a result of their thinking process after students see several sample questions, which can be used in solving math problems, after that repeat and predict the possibility of more difficult questions that the teacher will give later.

According to Palinscar \& Brown (1984), teaching reciprocal teaching is a learning approach that trains metacognition skills through four strategies, namely: 1) compiling questions from the reading text and answers, 2) making summaries of important information from the text reading, 3) making predictions, and 4) identifying things that are less clear and giving clarification (explanation).

Ibrahim, et all (2008) states that 1) trained skills and forms of activities carried out by students during learning activities, in reciprocal teaching have a positive impact on students 'communication skills, because during learning students ask questions, comment on other friends' answers, 2) according to Keller (1987) which is translated by Kardi (2002), on the ARCS motivation theory (Attention, Relevance, Confidence, Satisfaction), students will be motivated if what they learn attracts their attention, is relevant to students' needs, what they learn causes them to be satisfied, and adds trust himself. In reciprocal teaching-learning, students actively find out the information needed to answer their own questions so that they are relevant to their own needs, 3) during learning activities students make summaries, so they are trained to find key ideas in reading the material and this is an important skill for learning.

\section{Open-ended problem}

According to Shimada (1997), the openended approach begins with a view on how to objectively evaluate students' abilities and high-level mathematical thinking. In order for mathematics to be liked and learned by all students, closed problems that require a correct answer should be replaced by open-ended problems. Whereas according to Shimada (1997) said an openended approach is a learning approach that starts from introducing or confronting students in open-ended problems. An openended problem is a formulated problem that has many correct answers.

Heddens and Speer (Shimada, 1997) argue that open-ended can provide opportunities for students to play an active role and improve students' thinking. Open-ended provides flexibility for students to think actively and creatively in solving problems and highly appreciate the diversity of thinking that may arise during the problem-solving process (Mina, 2006).

Open problems themselves are rarely touched when presenting questions in the process of learning mathematics in school. As a result, if there are questions or problems that are considered 'wrong questions' or incomplete questions. In fact, such questions require students' creativity in answering them because they are required to think more than just remembering standard procedures in solving a problem. To solve this problem, students cannot get straight away so 
answer. This question requires a smarter way of thinking by planning before getting an answer so that it can explore students' creativity. To achieve the goal of assessment in mathematics above, it is necessary to have questions that can develop students' creative mindset through mathematical problems given by the teacher.

Russeffendi (1988) also states that to reveal or capture creative people it is better to use open (divergent) question questions, questions whose answers are more than one and cannot be predicted beforehand. Besides that, divergent questions require those asked to guess, make hypotheses, check whether the hypothesis is correct, review the solution thoroughly and make a decision. Divergent questions (open-ended questions) can be questions that ask students to analyze, explain, and make guesses, not just completing, finding, or counting.

The purpose of learning with open-ended questions is to help develop creative activities and mathematical mindset of students through simultaneous problem solving (simultaneous) (Nohda, 2001). In other words, learning by providing open questions is intended to develop the creative power and ability of students to think mathematically to the maximum in accordance with the quality and level of ability of the students concerned. Furthermore, Heddens and Speer (Rusoni, 2003) revealed that by giving open questions, can provide stimulation to students to improve their thinking, students have the freedom to express the results of the exploration of reasoning power and analysis actively and creatively in an effort to solve a problem.

\section{METHODS}

\section{Procedure}

The population in this study consisted of 2 types. Both types of populations are the target and affordable populations. The target population in this study were all students of SMP Negeri 1 Weru in the even semester of the academic year 2017/2018. Whereas the reachable population is class VII students of SMP Negeri 1 Weru consisting of 9 classes. The nine classes, starting from class VII-A to VII-I with the total number of students are 322. The technique of the sample was taken randomly by cluster random sampling technique (Bloom, Bos \& Lee, 1999). The acquisition of the research sample is as follows; class VII-E as the control class (36 students), class VII-G as the experimental class 1 (36 students) and class VII-H as the experimental class 2 (36 students).

The research method uses quantitative methods with the type of true experimental (Patten \& Newhart, 2017). While the research design used by researchers was randomized pretest-posttest control group design (Dimitrov \& Rumrill Jr., 2003; Arifin, 2011). As for more details can be seen in table 1.

Table 1.

Randomized Pretest-Posttest Control Group Design (Arifin, 2011)

\begin{tabular}{cccc}
\hline group & Pretest & Treatment & Posttest \\
\hline Experiment 1 & $\mathrm{O}_{1}$ & $\mathrm{X}_{1}$ & $\mathrm{O}_{2}$ \\
Experiment 2 & $\mathrm{O}_{1}$ & $\mathrm{X}_{2}$ & $\mathrm{O}_{2}$ \\
Control & $\mathrm{O}_{1}$ & - & $\mathrm{O}_{2}$ \\
\hline
\end{tabular}

Explanation:

$\mathrm{O}_{1}$ : pretest

$\mathrm{O}_{2}$ : posttest

$\mathrm{X}_{1}$ : The research class which in the learning process always applies the reciprocal teaching model assisted by the open-ended problem

$\mathrm{X}_{2}$ : The research class which in the learning process the implementation of the reciprocal teaching model is assisted by the problem of open-ended problems and conventional alternately

- : Research classes which in the learning process only apply conventional learning approaches

\section{Data Collection and Analysis Technique}

The instruments in this study were questionnaires and tests. Questionnaires are used to determine students 'responses in the application of reciprocal teaching models assisted by open-ended problem questions, while tests are used to measure 
students' critical thinking skills in mathematics.

The data analysis technique in this study is divided into two parts. The two parts are descriptive analysis techniques and inferential analysis techniques. Descriptive analysis techniques include tables of frequency distribution, range, minimum, maximum, sum, mean (mean), standard deviation, and variance (Hootman, 1992)). While inferential analysis uses the $\mathrm{F}$ test (One Way ANOVA) (Vangel \& Rukhin, 1999). But before the analysis is carried out, the data from the research results are carried out by the normality test and variance homogeneity test (Tiku, 1982). All data from the research results are analyzed with the help of SPSS 20. Then the hypothesis test is used to determine the suspicion formulated by researchers.

\section{FINDINGS AND DISCUSSION}

\section{The application of the reciprocal teaching approach}

According to Palinscar and Brown in Doolittle et al. (2006), the reciprocal teaching approach refers to an instructional activity that occurs in the form of a dialogue between teachers and students regarding the reading text. This reciprocal teaching model also provides opportunities for students to convey information to other students in relation to the summaries they have made. according to Griffin in Obiunu (2008) reveals that this dual role is useful because it allows students to gain understanding, both from their role as recipients of information and as people who convey information. Whereas according to Plinscar \& Brown (2006) there are four stages involved in the reciprocal teaching model namely summarizing, questioning, predicting, and clarifying. The stages in the reciprocal teaching model are expected to improve students' ability to understand the contents of the reading. Reciprocal teaching models emphasize students to work in a group that is formed in such a way that each member can communicate comfortably in expressing opinions or asking questions in order to exchange experiences of learning success with one another. The data from the results of the research on the application of the reciprocal teaching approach are aided by the open-ended problem. The description is as follows.

Table 2. Statistics Description of Student Response

\begin{tabular}{|c|c|c|c|c|c|c|c|}
\hline & Range & Minimum & Maximum & Sum & Mean & Deviation & Variance \\
\hline 136 & 29 & 62 & 91 & 2770 & 76,94 & 6,667 & 44,454 \\
\hline Experiment-2 36 & 23 & 61 & 84 & 2643 & 73,42 & 6,872 & 47,221 \\
\hline
\end{tabular}

Based on table 2, the maximum score of students' responses to the application of the reciprocal teaching approach was assisted by the experimental open-ended problem $1>$ experiment $2(91>84)$, the minimum score of the experimental class 1> experiment $2(62>61)$, the average obtained experimental class $1>$ experiment 2 (76.94> $73,42)$.

Based on the differences in the notation, it can also be explained that the corrected average student response in the experimental class 1 Reciprocal Teaching learning approach assisted with the openended problem is not significantly different and higher than the experimental class 2 .

\section{Data on students' critical mathematical thinking ability}

Critical thinking ability can be developed through mathematics learning in schools or colleges, which focuses on the system, structure, concepts, principles, and the tight link between an element and other elements (Maulana, 2008). Furthermore Ruggiero (Johnson, 2007) states that critical thinking is a life skill, not a hobby in the academic field. Then Johnson (2007) added that critical thinking is a hobby of thinking that can be developed by everyone, so this hobby must be taught in Elementary, Middle School, and High School. Recognizing the importance of developing students' critical thinking skills since elementary school, it is absolutely necessary for mathematics learning to involve students more actively in the learning process itself. 
The students' mathematical critical thinking ability is the total score obtained by students after working on the math problem that is measured includes aspects of interpretation, analysis, evaluation, conclusions, explanations, and independence. The data obtained will then be used as a measure to answer the hypothesis in this study. This research was conducted in three sample classes, namely experiment class 1 , experiment 2 , and control class. The description is as follows:

Table 3. Statistics description on pretest and posttest of experimental-1

\begin{tabular}{rrrrrrrrr}
\hline N & \multicolumn{1}{c}{ Range } & Minimum & Maximum & Sum & \multicolumn{1}{c}{ Mean l. Deviation } & Variance \\
\hline Pretest & 36 & 25 & 33,75 & 58,75 & 1531 & 42,53 & 6,328 & 40,043 \\
Posttest & 36 & 21 & 68,75 & 90 & 2885 & 80,14 & 5,104 & 26,052 \\
Valid N (listwise) & 36 & & & & & & & \\
\hline
\end{tabular}

Table 4. Statistics description on pretest and posttest of experimental-2

\begin{tabular}{|c|c|c|c|c|c|c|c|c|}
\hline & $\mathrm{N}$ & Range & himum I & imum & Sum & Mean & Deviation & Variance \\
\hline st & 36 & 31 & 23,75 & 55 & 1394 & $\begin{array}{l}38,72 \\
\end{array}$ & 7,334 & 53,793 \\
\hline $\begin{array}{r}\text { Posttest } \\
\text { Valid N (listwise) }\end{array}$ & $\begin{array}{l}36 \\
36\end{array}$ & 26 & 60,00 & 86,25 & 2623 & 72,85 & 7,813 & 61,037 \\
\hline
\end{tabular}

Tabel 5. The statistics description on pretest and posttest results of the control class

\begin{tabular}{|c|c|c|c|c|c|c|c|c|}
\hline & $\mathrm{N}$ & Range & Minimum & imum & Sum & Mean & Deviation & Variance \\
\hline Pretest & 36 & 23 & 30 & 52,50 & 1333 & 37,01 & 5,926 & 35,114 \\
\hline $\begin{array}{r}\text { Posttest } \\
\text { Valid N (listwise) }\end{array}$ & $\begin{array}{l}36 \\
36 \\
\end{array}$ & 33 & 50 & 82,50 & 2416 & 67,12 & 8,711 & 75,877 \\
\hline
\end{tabular}

Based on table 3 , the data of test spread in experimental class 1 obtained the maximum pretest score was 58.75 and the minimum score was 33.75 with the average obtained was 42.53. While the maximum score on posttest is 90 and the minimum score is 68.75 with the average obtained is 80.14 . Based on table 4, then the test spread data obtained in the experimental class 2 obtained the maximum score of the pretest was 55 and the minimum score was 23.75 with the average obtained was 38.72 . While the maximum score on the posttest is 86.25 and the minimum score is 60 with the average obtained is 72.85 . Based on table 5, the test distribution data obtained in the control class obtained the maximum pretest score was 52.50 and the minimum score was 30 with the average obtained was 37.01. while the maximum score at posttest is 82.50 and the minimum score is 50 with the average obtained is 67.12 .

\section{Implications of the Reciprocal Teaching Model Assisted base on the Open-Ended Problem Problem}

Data analysis of the improvement of critical thinking skills before and after applying the learning model was conducted to determine whether there was or no implication of the reciprocal teaching approach assisted by the open-ended problem in improving students' critical thinking skills in mathematics. Before the prerequisite test was carried out, the researchers looked for n-gain first to find out how much improvement in students' critical thinking skills based on the results of the pretest and posttest in each sample class. It was found that the average gain of the experimental class $>$ experimental class $2>$ control class $(0.65>0.56>0.46)$. So that it can be concluded that the value of $n$-gain class treated with the application of the reciprocal teaching model is assisted by the open-ended problem questions higher than the class that does not receive the reciprocal teaching model assisted by the open-ended problem..

Normality testing is carried out on data from the experimental-1 N-Gain, experiment-2, and control class. As for the results of the analysis, there is 1). Statistical values for Kolmogorov-Smirnov are 0.128 and Sig. $=0.145>0.05, \mathrm{H} 0$ is accepted or not significant. thus, the experimental-1 N-Gain data is normally distributed. 2) Statistical values for Kolmogorov-Smirnov are 0.072 and Sig. = $0.200>0.05, \quad \mathrm{HO}$ is accepted or not significant. thus, the experimental-2 $\mathrm{N}$ - 
Gain data is normally distributed, and 3) Statistical values for Kolmogorov-Smirnov are 0.104 and Sig. $=0.200>0.05, \mathrm{H} 0$ is accepted or not significant. thus, the control class N-Gain data is normally distributed.

Homogeneity testing was carried out on $\mathrm{N}$ Gain data in experimental class 1, experiment 2 , and control class. The data obtained from the analysis shows that Sig. greater than then it can be said that the variant is the same. based on the results of the analysis in table 8, obtained $\mathrm{F}$ for
1.796; df1 $=2 ; \mathrm{df2}=105 ;$ and $=0.171>0.05$, therefore it can be concluded that $\mathrm{HO}$ is rejected, and the N-Gain data is homogeneous..

Next is testing the hypothesis. The testing of hypothesis testing in this study using the One Way Anova test. The analysis was conducted on the experimental class $1 \mathrm{~N}$ Gain data, experiment 2, and the control class. The data from the analysis are as follows table 6 .

Table 6. ANOVA

\begin{tabular}{rrrrrr}
\hline & Sum of Squares & df & Mean Square & F & Sig. \\
\hline Between Groups &, 528 & 2 &, 264 & 25,213 &, 000 \\
Within Groups & 1,100 & 105 &, 010 & & \\
Total & 1,629 & 107 & & & \\
\hline
\end{tabular}

Based on table 6 , the $\mathrm{F}_{\text {count }}$ value is greater than $\mathrm{F}_{\text {table }}(25.213>5.34)$, so $\mathrm{H} 0$ is rejected and the significance value is $<\alpha=0,000$ $<0.05$, so it can be concluded that there is a significant difference between mathematical critical thinking skills of students in experimental class 1 , experiment 2 , and the control class.
Furthermore, it is necessary to further analyze which pairs of groups have significant differences. In education that is commonly used is Tukey's HSD, in this case, the Tukey test is used to find out the significant differences in treatment. The output is as follows::

Table 7. Multiple Comparisons

\begin{tabular}{|c|c|c|c|c|c|c|}
\hline \multicolumn{7}{|c|}{$\begin{array}{c}\text { Dependent Variable: VALUE Gain } \\
\text { Tukey HSD }\end{array}$} \\
\hline \multirow{2}{*}{ (I) KELAS } & \multirow{2}{*}{\multicolumn{2}{|c|}{ (J) KELAS ın Difference (I-J) }} & \multirow{2}{*}{ Std. Error } & \multirow{2}{*}{ Sig. } & $95 \%$ Confi & dence Interval \\
\hline & & & & & Lower Bound & Upper Bound \\
\hline \multirow{2}{*}{ Experiment-1 } & Experiment-2 &, $09232^{*}$ & ,02413 & ,001 & 0350 &, 1497 \\
\hline & control &, $17115^{*}$ & ,02413 & ,000 & ,1138 & ,2285 \\
\hline \multirow{2}{*}{ Experiment-2 } & Experiment-1 &,$- 09232^{*}$ & 02413 & ,001 &,- 1497 &,- 0350 \\
\hline & control &, $07883^{*}$ & 02413 & 004 & 0215 &, 1362 \\
\hline \multirow{2}{*}{ control } & Experiment-1 &,$- 17115^{*}$ & 02413 & ,000 &,- 2285 &,- 1138 \\
\hline & Experiment-2 &,$- 07883^{*}$ & 02413 & ,004 &,- 1362 &,- 0215 \\
\hline
\end{tabular}

Table 7. Multiple Comparisons provide information about the significance of differences in each possible pair. Then the table is mapped by researchers to become a chart for applying the learning model as follows.

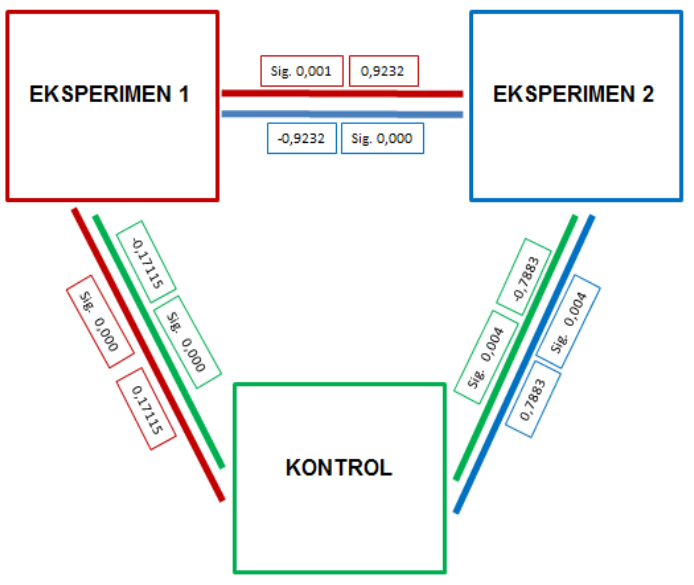


Figure 1. Chart of Implications for the Application of Learning Models

Chart the implications of applying the learning approach to provide information about the significance of differences in each possible partner. Here's the explanation:

a. Between experimental class 1 and experimental class 2 , the difference is significant, indicated by a significance value of 0.01 . If the significance value is $<0.05$, it shows that there is a difference between experimental class 1 and experimental class 2. Because the mean difference value is more than 0 (zero), this indicates that the mathematics critical thinking ability of experimental class 1 students is better than the ability Mathematical critical thinking students of experimental class 2. It can be said that the reciprocal teaching model is assisted by open-ended problem questions which have implications in improving students' critical thinking skills in mathematics.

b. Between experimental class 1 and control class, the difference is significant, indicated by a significance value of 0.00 . If the significance value is $<0.05$, it shows that there is a difference between the experimental class 1 and the control class. Because the mean difference value is more than 0 (zero), this indicates that the mathematics critical thinking ability of the experimental class 1 students is better than the control class students. Then it can be said that the reciprocal teaching model is assisted by open-ended problem questions which have implications in improving students' critical thinking skills in mathematics.

c. Between experimental class 2 and control class, the difference was significant, indicated by a significance value of 0.04 . If the significance value is $<0.05$, this indicates that there is a difference between the experimental class 2 and the control class. Because the mean difference value is more than 0 (zero), this indicates that the mathematics critical thinking ability of the experimental class 2 students is better than the control class students. Then it can be said that the reciprocal teaching model is assisted by open-ended problem questions which have implications in improving students' critical thinking skills in mathematics.

Based on the hypothesis test above, it can be seen that the average results of students 'critical thinking skills by applying the reciprocal teaching model are assisted by the higher open-ended problem questions compared to the average results of students' critical thinking skills who do not apply assisted models of reciprocal teaching open-ended problem questions so that it can be concluded that: "The reciprocal teaching model is assisted with open-ended problem questions which have implications for improving students' mathematical critical thinking skills.

All of these descriptions turned out to be in line with the results of research that implemented this reciprocal teaching, had succeeded in improving low learning achievement (Palincsar \& Brown, 1984; Palinscar in Slavin 1994). The weakness in teaching reciprocal teaching is the saturation of students who are faced with the understanding of textbooks only (especially in students who are passive) and not all students get a part to become "student teachers", even though many active students want to be involved in dialogue " students "(Khabibah, 1999; Efendi, 2005).

Reducing existing weaknesses, reciprocal teaching-learning can be created a learning atmosphere that emphasizes the meaning of togetherness, such as think pair share. As the name implies think pair share, the syntax of this strategy is: 1) begins with "thinking" by the way the teacher asks questions or issues related to the lesson for students to think about, 2) "pairing", the teacher asks students to pair up to discuss , 3) "sharing", the results of discussion between students in each pair.

\section{CONCLUSION}

Based on the description of statistical analysis and discussion, the writer can draw conclusions as follows:

1. Student responses to the application of the learning approach between the experimental class 1 and the 
experimental class 2 produce different values in each aspect. Experimental class 1 are better than experimental class 2, This shows that the application of the reciprocal teaching model is assisted by open-ended problems both used in mathematics learning.

2. There was an increase in students' mathematical critical thinking skills. Where the critical thinking ability of the experimental class 2 is higher than the control class. While the mathematics critical thinking ability of the experimental class 1 students is higher than the experimental class 2 .

3. Significant implications occur in the results of applying learning approaches to students' mathematical critical thinking skills. this happened in the experimental class 1 with experimental class 2 with a mean difference of 0.9232 , the significance value of $0.01<0.05$. While the significance of the implications of the application of the learning approach between the experimental class 1 and the control class with the mean difference of 0.17115 , a significance value of $0.00<0.05$. In addition, there are implications for the application of a significant learning model between the experimental class 2 students and the control class with a mean difference of 0.7883 with a significance value of 0.04 $<0.05$.

\section{ACKNOWLEDGMENTS}

The authors wish to thank Faculty of Tarbiyah and Teacher Science (FITK) IAIN Syekh Nurjati Cirebon-Indonesia

\section{REFERENCES}

Aizikovitsh, E. \& Amit, M. (2010). Evaluating an infusion approach to the teaching of critical thinking skills through mathematics. Procedia-Social and Behavioral Sciences, 2 (1), 3818- 3822

Arifin, Z. (2011). Penelitian Pendidikan: Metode dan Paradigma Baru. Jakarta: PT Remaja Rosdakarya.
Baker, R. (2017). Problem-solving. In Agile UX Storytelling (pp. 107-116). Apress, Berkeley, CA.

Baker, S., Gersten, R., \& Lee, D. S. (2002). A synthesis of empirical research on teaching mathematics to lowachieving students. The Elementary School Journal, 103(1), 51-73.

Biggs, J. (2001). The reflective institution: Assuring and enhancing the quality of teaching and learning. Higher education, 41(3), 221-238.

Bloom, H. S., Bos, J. M., \& Lee, S. W. (1999). Using cluster random assignment to measure program impacts: Statistical implications for the evaluation of education programs. Evaluation Review, 23(4), 445-469.

Boaler, J. (1998). Open and closed mathematics: Student experiences and understandings. Journal for research in mathematics education, 41-62.

Brown, A. L., \& Palincsar, A. S. (1987). Reciprocal teaching of comprehension strategies: A natural history of one program for enhancing learning. Ablex Publishing.

Chukwuyenum, A.N. (2013). Impact of Critical thinking on Performance in Mathematics among Senior Secondary School Students in Lagos State. Journal of Research \& Method in Education, 3(5), 18-25

Cobb, P; Wood, T; Yackel, E. \& McNeal, B. (1992). Characteristics of Classroom mathematics Tradition: An interactional analysis. American Educational Research Journal, 29, 573-604

Dimitrov, D. M., \& Rumrill Jr, P. D. (2003). Pretest-posttest designs and measurement of change. Work, 20(2), 159-165.

Doolittle, P. E., Hicks, D., Triplett, C. F., Nichols, W. D., \& Young, C. A. (2006). Reciprocal teaching for reading comprehension in higher education: A strategy for fostering the deeper understanding of texts. International Journal of 
Teaching and Learning in Higher Education, 17(2), 106-118.

Dowaliby, F., \& Schumer, H. (1973). Teacher-centered versus studentcentered mode of college classroom instruction as related to manifest anxiety. Journal of Educational Psychology, 64(2), 125.

Duplass, J.A. \& Ziedler, D.L. (2002). Critical thinking and logical argument. Social Education, 66(5), 10-14

Efendi, N. (2005). Penerapan pengajaran terbalik (reciprocal teaching) untuk menuntaskan hasil belajar siswa sltp pada pokok bahasan perkembangbiakan tumbuhan. Tesis. Surabaya: Pascasarjana UNESA

Ennis, R.H. (1996). Critical Thinking, New Jersey : Prentice Hall, Inc

Facione, P.A. (2011). Critical Thinking: What It Is and Why It Counts. Millbrae, CA: The California Academic Press

Facione, P.A. (2011). Critical Thinking: What It Is and Why It Counts. Millbrae, CA: The California Academic Press

Fisher, A. (2009). Berpikir Kritis: Sebuah Pengantar. Jakarta: Erlangga.

Glazer, E. (2001). Using Internet Primary Sources to Teach Critical Thinking Skills in Mathematics. Westport, CT: Greenwood Publishing Group

Granger, E. M., Bevis, T. H., Saka, Y., Southerland, S. A., Sampson, V., \& Tate, R. L. (2012). The efficacy of student-centered instruction in supporting science learning. Science, 338(6103), 105108.

Hastanti, S. S. (2009). Keefektifan Model Pembelajaran Reciprocal Teaching Terhadap Kemampuan Berpikir Kritis dalam Materi Pokok Segiempat di Kelas VII SMP Negeri 4 Pemalang.Universitas Negeri Semarang.

Henningsen, M. \& Stein, M.K. (1997). Mathematical tasks and student cognition: classroom-based factors that support and inhibit high-level mathematical thinking and reasoning. Journal for Research in Mathematics Education, 25(5), 524549

Hootman, R. C. (1992). Manual on descriptive analysis testing for sensory evaluation. Philadelphia, PA:: ASTM.

Husnidar, Ikhsan, M., \& Rizal, S. (2014). Penerapan Model Pembelajaran Berbasis Masalah Untuk Meningkatkan Kemampuan Berpikir Kritis dan Disposisi Matematis Siswa. JurnalDidaktik Matematika, 1(1), 71-82.

Ibrahim, M., Rachmadiarti, F., Nur, M, \& Ismono. (2000). Pembelajaran Kooperatif. Surabaya: Unesa University Press

Innabi, H., \& Sheikh, O.E. (2006). The change in mathematics teachers' perceptions of critical thinking after 15 years of educational reform in Jordan, Educational Studies in Mathematics, 64, 45-68

Jacob, S. M., \& Sam, H. K. (2008). Measuring critical thinking in problem solving through online discussion forums in First Year University Mathematics. In Proceedings of the Internationals MultiConference of Engineers and Computer Scientists (IMECS), Hong Kong.

Jacob, S.M. (2012). Mathematical achievement and critical thinking skills in asynchronous discussion forums. Procedia - Social and Behavioral Sciences, 31 (2012), 800 $-804$

Johnson, E. B. (2007). Contextual Taching And Learning: Menjadikan Kegaiatn BelajarMengajar Mengasyikkan Dan Bermakna. Bandung: Mizan Learning Center (MLC)

Kardi, S. (2002). Strategi Motivasi ARCS. Surabaya: Universitas Negeri Surabaya.

Keller, J. M. (1987). Strategies for stimulating the motivation to 
learn. Performance+

Instruction, 26(8), 1-7.

Khabibah, S. (1999). Pengembangan perangkat pembelajaran bedasarkan prinsip pengajaran terbalik pada pokok bahasan persamaan linear di SMU. Tesis. Surabaya: Pascasarjana Universitas Negeri Surabaya

Krulik, S. \& Rudnick, J.A. (1995). The New Sourcebook for Teaching Reasoning and Problem Solving in Elementary School. Needham Heights: Allyn dan Bacon.

Kusmanto, H. (2014). Pengaruh Berpikir Kritis Terhadap Kemampuan Siswa dalam Memecahkan Masalah Matematika (Studi Kasus di Kelas VII SMP Wahid Hasyim Moga). Jurnal EduMa, 3(1), 92-106.

Lakatos, I. (2015). Proofs and refutations: The logic of mathematical discovery. Cambridge university press.

Lewis, A. \& Smith, D. (1993). Defining Higher Order Thinking. Teory into Practice, 32(3), 131-137

Mason, J., Burton, L. \& Stacey, K. (2010). Thinking Mathematically, 2nd edition. London: Pearson Education Limited.

Maulana. (2008). Pendekatan Metakognitif Sebagai Alternatif Pembelajaran Metematika Untuk Meningkatkan Kemampuan Berpikir Kritis Mahasiswa PGSD. Jurnal Pendidikan Dasar. (10). 39-46.

Mina, E 2006. Pengaruh Pembelajaran Matematika dengan Pendekatan Open-ended terhadap kemampuan Berpikir Kreatif Matematika Siswa SMA Bandung. Bandung: Tesis pada PPs UPI.

Mullis, I., Martin, M.O. \& Foy, P. (2012). TIMSS 2011 International Results in Mathematics. Chestnut Hill: TIMSS \& PIRLS International Study Center

NCTM. (2000). Principles and Standards For School Mathematics. Reston, VA: NCTM

Newman, D., Griffin, P. \& Cole, M. (1989). The Construction Zone: Working
For Cognitive Change in School. Mass: Cambridge University Press

Nohda, N. (2001). A study of "openapproach" method in school mathematics teaching-focusing on mathematical problem solving activities. Institute of Education. University of Tsukuba.

Obiunu, J. J. (2008). The effects of reciprocal peer tutoring on the enhancement of career decision making process among secondary school adolescents. Educational Research and Reviews, 3(7), 236241.

Oczkus, L. D. (2018). Reciprocal teaching at work: Powerful strategies and lessons for improving reading comprehension. ASCD.

OECD. (2014). PISA 2012 Results: What Students Know and Can Do Student Performance in mathematics, Reading and Science. revised edition (Februari).Volume I: OECD Publishing

Oreck, B. (2004). The artistic and professional development of teachers: A study of teachers' attitudes toward and use of the arts in teaching. Journal of Teacher education, 55(1), 55-69.

Palincar, A \& Brown,A. (1984). Model Reciprocal Teaching of Comprehentionforestering and Comprehention-monitoring Activities. Cognition and Instruction

Palincsar, A. S., \& Brown, A. L. 1986. Interactive Teaching to Promote Independent Learning From Text. The Reading Teacher 39 (8): 71-77

Palinscar, A. S., \& Brown, A. L. (1984). Reciprocal teaching of comprehension-fostering and comprehension-monitoring activities. Cognition and instruction, 1(2), 117-175.

Palmer, J. A. (2002). Environmental education in the 21st century: Theory, practice, progress and promise. Routledge.

Patten, M. L., \& Newhart, M. (2017). Understanding research 
methods: An overview of the essentials. Routledge.

Perkins, C., \& Murphy E. (2006). Identifying and measuring individual engagement in critical thinking in online discussions: An exploratory study. Educational Technology \& Society, 9(1), 298-307

Rajendran, N.S. (2010). Teaching and Acquiring Higher Order Thinking Skills: Theory and Practice. Tanjong Malim, Perak: Penerbit Universiti Pendidikan Sultan Idris

Rohaeti, E.E. (2010). Critical and Creative Mathematical Thinking of Junior High School Student. Educationist Journal, 4(2), 99-106

Rosenshine, B., \& Meister, C. (1994). Reciprocal teaching: A review of the research. Review of educational research, 64(4), 479-530.

Ruseffendi, E.T. 1988. Pengantar Kepada Membantu Guru Mengembangkan Kompetensinya dalam Pengajaran Matemática. Bandung: Tarsito

Rusoni, Elin. 2003. Pembelajaran Matematika dengan Open-ended approach. Buletin LPPG

Semerci, C. (2005). The influence of critical thinking skills on students' achievement. Pakistan Journal of Social Sciences, 3(4), 598-602

Shimada, S dan Becker J.P. (1997) The open-ended approach: $A$ new Proposal for Teaching Mathematics. Virginia : National Cauncil of Teachers of Mathematics

Silver, E.A. and Kenney, P.A. (1995). Sources of Assessment Information for Instructional Guidance in Mathematics. In T.A. Romberg (Ed.). Reform in School Mathematics and Authentic Assessment (pp. 38-68). Albany: State University of New York Press

Slavin, R.E. (1994). Educational psychology: theories and practice. Fourth Edition. Massachussetts: Allyn and Bacon Publishers.

Soedjadi, R. (2000). Kiat Pendidikan Matematika di Indonesia: Konstatasi Keadaan Masa Kini
Menuju Harapan Masa Depan. Jakarta: Dirjen Dikti Depdiknas

Tiku, M. L. (1982). Testing linear contrasts of means in experimental design without assuming normality and homogeneity variances. Biometrical Journal, 24(6), 613-627.

Trianto. (2007). Model Pembelajaran Inovatif Berorientasi Konstruktivis. Jakarta: Prestasi Pustaka Publisher.

Vangel, M. G., \& Rukhin, A. L. (1999). Maximum likelihood analysis for heteroscedastic one-way random effects ANOVA in interlaboratory studies. Biometrics, 55(1), 129-136.

Vickers, J. N. (1990). Instructional design for teaching physical activities: $A$ knowledge structures approach. Human Kinetics Publishers

Wijaya, A. (2011). Pendidikan Matematika Realistik: Suatu Alternatif Pendekatan Pembelajaran Matematika. Yogyakarta: Graha Ilmu.

Winarso, W. (2015). Dasar Pengembangan Kurikulum Sekolah. Cirebon: CV. Confident.

Zohar, A. \& Dori, Y.J. (2003). Higher Order Thinking Skills and Low Achieving Students: Are They Mutually Exclusive? Journal of the Learning Sciences, 12, 145-181 
24 EduMa Vol. 8 No. 1 Juli 2019

ISSN 2086 - 3918 